Innowacje w Pielęgniarstwie i Naukach o Zdrowiu

1(1)/2016

ISSN: 2451-1846

DOI: http://dx.doi.org/10.21784/IwP.2016.001

Leokadia Rezmerska ${ }^{1}$, Dorota Kochman ${ }^{1}$, Agnieszka Anaszewicz ${ }^{2}$

${ }^{1}$ Państwowa Wyższa Szkoła Zawodowa we Włocławku

${ }^{2}$ Wojewódzki Szpital Specjalistyczny we Włocławku

\title{
Specyfika pracy a wypalenie zawodowe w opinii pielęgniarek
}

\section{The specificity of the work and professional burnout in nurses opinion}

\section{Streszczenie:}

Wstęp. Charakter pracy pielęgniarki w oddziałach szpitalnych powoduje, że pielęgniarka narażona jest na działanie różnych czynników stresogennych przyczyniających się do powstania zjawiska wypalenia zawodowego. Sytuacja ta występuje z powodu długotrwałego stresu i nieskutecznego radzenia sobie z przeciążeniami zawodowymi. Mianem wypalenia zawodowego określany jest stan charakteryzujący się frustracją i wyczerpaniem, pojawiający się u osób, które w pracy intensywnie zajmują się innymi poświęcając temu wiele energii tak, że dochodzi do utraty sił i motywacji do kontynuowania pracy z dotychczasową intensywnością i zaangażowaniem. Model zespołu wypalenia zawodowego jest trójstopniowy i obejmuje wyczerpanie emocjonalne, depersonalizację oraz obniżone poczucie dokonań osobistych. Wskutek wypalenia zawodowego następuje utrata zaangażowania zawodowego i obniżenie satysfakcji zawodowej co prowadzi do obniżenia jakości i efektywności świadczonej opieki medycznej. W związku z tym podejmowane są działania zapobiegające temu zjawisku w środowisku pracy nie tylko ze 
względu na jego skutki zdrowotne i wydajność pracy ale także ze względu na bezpieczeństwo i dobro podopiecznych.

Cel. Celem pracy było określenie i zbadanie wpływu warunków środowiska pracy na poziom zjawiska wypalenia zawodowego wśród pielęgniarek oddziałów szpitalnych.

Materiał i metody. Badania przeprowadzono w 2013 roku, w grupie 70 pielęgniarek zatrudnionych w Wojewódzkim Szpitalu Specjalistycznym we Włocławku w 4 oddziałach szpitalnych. Badania wykonano metodą sondażu diagnostycznego z użyciem kwestionariusza ankiety własnej konstrukcji. Wyniki. Dominującą grupą osób badanych pod względem wieku były pielęgniarki od 41 do 50 roku życia z długim stażem pracy od 21 do 30 lat i o wykształceniu na poziomie średniej szkoły medycznej. Bardziej liczną grupę stanowiły pielęgniarki ze zmianowym charakterem pracy. Wyniki badań dotyczą analizy poziomu wypalenia zawodowego wśród pielęgniarek pod względem rodzaju oddziału szpitalnego.

Wnioski: 1.Charakter pracy pielęgniarek w oddziałach szpitalnych różnicuje poziom zjawiska zespołu wypalenia zawodowego. Wyższy poziom wypalenia zawodowego występuje w oddziałach zabiegowych w porównaniu z oddziałami zachowawczymi. 2. Praca pielęgniarek w systemie wielozmianowym powoduje wystąpienie wyższego poziomu wypalenia zawodowego niż praca jednozmianowa. 3. Pielęgniarki mające niskie poczucie satysfakcji zawodowej prezentują wyższy poziom wypalenia zawodowego. 4. Pielęgniarki znają i potrafią identyfikować symptomy zjawiska wypalenia zawodowego, jak również sposoby radzenia sobie ze stresem i przeciwdziałania jego ujemnym skutkom.

\begin{abstract}
:
Introduction. The nature of a nurse's work in hospital wards makes the nurse exposed to various stress provoking factors that contribute to the emergence of the burnout phenomenon. This situation occurs due to prolonged stress and ineffective coping with overloads at work. Burnout is defined a as condition characterized by frustration and exhaustion appearing in people who take intensive care of others devoting so much energy, which results in the loss of energy and motivation to continue working with the previous intensity and commitment. The model of professional burnout syndrome is a three-stage process and includes emotional exhaustion, depersonalization, and reduced sense of personal accomplishment. As a result of
\end{abstract}


burnout there occurs the loss of professional commitment and decrease of satisfaction with the job which leads to a reduction in the quality and effectiveness of medical care provided. Therefore, actions are taken to prevent this phenomenon in the work environment, not only because of its effects on health and the effectiveness of work but also because of the safety and welfare of patients.

Aim. The aim of this study was to determine and investigate the effect of environmental conditions on the level of the phenomenon of burnout among nurses at hospital wards.

Material and methods. The study was carried out in 2013, in a group of 70 nurses working in the Provincial Specialist Hospital in Wloclawek in 4 wards. The study was performed by means of diagnostic survey with the use of a questionnaire of our own design.

Results. The dominant group of those surveyed in terms of age were nurses aged from 41to 50 years with long years of service ranging from 21 to 30 years and with the education at the level of the secondary medical school. A more numerous group consisted of nurses with shift system of work. The results of the research refer to the analysis of the level of burnout among nurses in terms of the type of the hospital ward.

Conclusions. 1 . The nature of the work of nurses in hospital wards varies the level of the phenomenon of professional burnout syndrome. Higher levels of burnout occurs in surgical wards as compared to conservative wards. 2. The work of nurses in multi-shift system of work causes a higher level of burnout than single shift system. 3. Nurses having a low sense of professional satisfaction represent a higher level of burnout. 4. Nurses know and are able to identify the symptoms of the phenomenon of burnout, as well as the ways of coping with stress and preventing its negative effects.

Słowa kluczowe: specyfika pracy, wypalenie zawodowe, pielęgniarka

Keywords: the specificity of work, burnout, nurse

\section{Wstęp}

Specyfika pracy pielęgniarki w oddziałach szpitalnych powoduje, że pielęgniarka narażona jest na działanie różnych czynników stresogennych przyczyniających się do powstania zjawiska wypalenia zawodowego. Sytuacja ta jest konsekwencją długotrwałego stresu i nie- 
skutecznego radzenia sobie z przeciążeniami zawodowymi. Problem jakim jest zespół wypalenia zawodowego pierwszy raz został podjęty przez amerykańskiego psychiatrę H. Freudenberga w 1974 r. To właśnie pielęgniarki, których praca wymaga stałego kontaktu z oczekującymi pomocy ludźmi stały się głównym obiektem podjętych wówczas badań naukowych. Wykonując powierzone obowiązki pielęgniarki niejednokrotnie muszą radzić sobie z ogromnym obciążeniem emocjonalnym i psychicznym. Problem zaczyna pogłębiać się w momencie pojawienia się czynników przyczyniających się do narastania rozczarowania, frustracji i negatywnych emocji w środowisku pracy. Mianem wypalenia zawodowego określany jest stan charakteryzujący się frustracją i wyczerpaniem, pojawiający się u osób, które w pracy intensywnie zajmują się innymi poświęcając temu tak wiele energii psychicznej i fizycznej, że nie mają siły i motywacji do kontynuowania swojej pracy z dotychczasową intensywnością i zaangażowaniem [1]. Według C. Maslach występuje trójwymiarowy model procesu wypalenia zawodowego, który obejmuje wyczerpanie emocjonalne, depersonalizację oraz obniżone poczucie dokonań osobistych [2]. W początkowym stadium są to objawy zmęczenia, drażliwość, utrata energii, zniechęcenie, brak cierpliwości, obojętność, bezoosobowe traktowanie podopiecznych, utrzymująca się złość, trudności w wyrażaniu własnych opinii. $\mathrm{W}$ dalszej kolejności narasta poczucie niezadowolenia, niekompetencji, pokrzywdzenia i utrata sensu pracy [3,4]. Wypalenie zawodowe pociąga za sobą wiele negatywnych konsekwencji dla pracownika w wielu jego dziedzinach życia. Wskutek wypalenia zawodowego następuje utrata zaangażowania zawodowego i obniżenie satysfakcji zawodowej co prowadzi do obniżenia jakości i efektywności świadczonej opieki medycznej. W związku z tym istotne staje się zapobieganie temu zjawisku w środowisku pracy nie tylko ze względu na jego skutki zdrowotne i wydajność pracy ale także ze względu na bezpieczeństwo i dobro podopiecznych. 
Celem pracy było określenie i zbadanie wpływu warunków środowiska pracy na poziom zjawiska wypalenia zawodowego wśród pielęgniarek oddziałów szpitalnych.

\section{Materiał i metody}

Badania zostały przeprowadzone w 2013 roku w okresie od sierpnia do października, $\mathrm{w}$ grupie 70 pielęgniarek zatrudnionych w Wojewódzkim Szpitalu Specjalistycznym we Włocławku w 4 oddziałach szpitalnych. Na wykonanie badań uzyskano zgodę Komisji Bioetycznej Kujawsko-Pomorskiej Okręgowej Izby Lekarskiej w Toruniu (34/KB/2013). W celu realizacji badań wykorzystano metodę sondażu diagnostycznego z użyciem kwestionariusza ankiety własnej konstrukcji zawierającego 20 pytań zamkniętych jednokrotnego i wielokrotnego wyboru. Analizę statystyczną wyników badań wykonano przy pomocy programu Statistica 10.0 stosując współczynnik korelacji R Spearmana, nieparametryczny test U Manna-Whitneya oraz test rang Kruskala-Wallisa. Dla wszystkich analiz przyjęto współczynnik istotności na poziomie 0,05 .

\section{Wyniki}

W badaniach uczestniczyło 70 pielęgniarek o zróżnicowanych cechach zawodowych i demograficznych. Tabela 1 prezentuje charakterystykę grupy badanych pielęgniarek.

Tabela 1. Charakterystyka badanej grupy.

\begin{tabular}{|l|l|c|c|}
\hline \multirow{2}{*}{ Cechy } & \multicolumn{1}{|c|}{ Parametry } & \multicolumn{2}{c|}{ Wartości } \\
\cline { 2 - 4 } & & $\mathbf{n}$ & $\mathbf{\%}$ \\
\hline \multirow{4}{*}{ Wiek } & $21-30$ lat & 2 & 2,9 \\
\cline { 2 - 4 } & $31-40$ lat & 11 & 15,6 \\
\cline { 2 - 4 } & $41-50$ lat & 37 & 52,9 \\
\cline { 2 - 4 } & 51-60 lat & 20 & 28,6 \\
\hline \multirow{3}{*}{ Staż pracy } & $1-10$ lat & 9 & 12,8 \\
\cline { 2 - 4 } & $11-20$ lat & 10 & 14,3 \\
\hline
\end{tabular}




\begin{tabular}{|l|l|c|c|}
\hline \multirow{5}{*}{ Wykształcenie } & $21-30$ lat & 34 & 48,6 \\
\cline { 2 - 4 } & $31-40$ lat & 17 & 24,3 \\
\hline \multirow{5}{*}{ System pracy } & Średnie zawodowe & 36 & 51,4 \\
\cline { 2 - 4 } & Wyższe zawodowe & 28 & 40,0 \\
\cline { 2 - 4 } & Wyższe magisterskie & 6 & 8,6 \\
\hline \multirow{5}{*}{ Miejsce pracy } & Jednozmianowa & 15 & 21,4 \\
\cline { 2 - 4 } & Dwuzmianowa & 54 & 77,6 \\
\cline { 2 - 4 } & Oddział Okulistyczny & 10 & 14,3 \\
\cline { 2 - 4 } & Oddział Chirurgiczny & 20 & 28,6 \\
\cline { 2 - 4 } & Oddział Internistyczny & 19 & 27,1 \\
\cline { 2 - 4 } & $\begin{array}{l}\text { Szpitalny Oddział Ratun- } \\
\text { kowy }\end{array}$ & 21 & 30,0 \\
\hline
\end{tabular}

Źródło: opracowanie własne.

Dominującą grupę osób badanych pod względem wieku stanowiły pielęgniarki od 41 do 50 roku życia (52,9\%). Najmniej liczna grupa wiekowa to wiek od 21 do 30 roku życia (2,9\%). U zdecydowanej większości osób występował długi staż pracy i wynosił od 21 do 30 lat (48,6\%). W zakresie wykształcenia dominującą grupę stanowiły pielęgniarki $\mathrm{z}$ wykształceniem na poziomie średniej szkoły medycznej (51,4\%). Zdecydowanie liczniejszą grupę stanowili badani, których praca miała charakter zmianowy $(77,1 \%)$.

Analiza statystyczna wyników badań polegała na ocenie zjawiska wypalenia zawodowego pielęgniarek w zależności od wybranych czynników demograficznych i warunków środowiska pracy. Wszystkie badane pielęgniarki stwierdzają jednomyślnie, że znają określenie i problematykę zjawiska wypalenia zawodowego.

Analiza poziomu wypalenia zawodowego pod względem grup wiekowych dowiodła, że zespół wypalenia kształtuje się zdecydowanie w największym zakresie na poziomie średnim we wszystkich grupach wiekowych, co dotyczy $64,7 \%$ badanej populacji. Natomiast jako niski poziom dominował $\mathrm{w}$ grupie wiekowej 51-60 lat (30\%), a jako 
wysoki w grupie $31-40$ lat $(15,4 \%)$. Zależności te jednak nie są istotnie zależne statystycznie $(\mathrm{p}<0,322)$.

W analizie wyników nie zanotowano również istotnego statystycznie związku pomiędzy poziomem wypalenia zawodowego a stażem pracy $(\mathrm{p}<0,540)$. We wszystkich grupach podziału ze względu na długość stażu pracy dominuje średni poziom wypalenia zawodowego. Jednocześnie zaobserwowano, że wysoki poziom wypalenia występuje najczęściej u osób z krótkim stażem pracy, to jest od 1 roku do 10 lat $(22,2 \%)$. Natomiast niski poziom wypalenia posiadają najczęściej osoby ze stażem pracy od 21-30 lat (26,5\%).

Ankietowane pielęgniarki ze względu na rodzaj wykształcenia odczuwają $\mathrm{w}$ dominującym zakresie średni poziom wypalenia zawodowego. Jednak pielęgniarki z wykształceniem wyższym magisterskim aż w 50\% posiadają niski poziom wypalenia zawodowego. Natomiast pielęgniarki z wykształceniem średnim zawodowym prezentują wysoki poziom wypalenia, co stanowi 19,4\% osób badanych. W toku powyższej analizy stwierdzono, że różnice te są istotne statystycznie $(\mathrm{p}<0,013)$.

Poziom zespołu wypalenia zawodowego różni się istotnie w zależności od charakteru pracy badanych pielęgniarek $(\mathrm{p}<0,020)$. Zarówno praca zmianowa jak i praca jednozmianowa powodują w największym stopniu wystąpienie zespołu wypalenia zawodowego na poziomie średnim. Zdecydowana większość pielęgniarek w pracy jednozmianowej określa poziom wypalenia jako niski (46,7\%), a poziom wysoki występuje w pracy zmianowej pielęgniarek u16,4\% osób badanych.

Wykonana analiza wyników badań wykazała również istotną zależność statystyczną zespołu wypalenia zawodowego i rodzaju oddziału szpitalnego jako miejsca pracy pielęgniarek $(\mathrm{p}<0,001)$. Najczęściej poziom wypalenia określany był jako średni, zarówno wśród pielęgniarek oddziałów zabiegowych (chirurgia i okulistyka) jak i niezabiegowych (interna i SOR). Natomiast jako poziom wysoki po- 
daje 17,6\% osób badanych z oddziałów zabiegowych, a poziom niski wymienia 31,6\% osób z oddziałów niezabiegowych.

Analizując wyniki badań dotyczące oceny poziomu wypalenia zawodowego w zależności od satysfakcji zawodowej stwierdzono, że badani, którzy odczuwają niską satysfakcję prezentują wysoki poziom wypalenia. Zależność ta jest istotna statystycznie $(\mathrm{p}<0,001)$.

W pracy zawodowej pielęgniarki nieodłącznym elementem jej działań jest stres, który wpływa niekorzystnie na stan zdrowia psychicznego i fizycznego oraz przyczynia się do wystąpienia objawów zespołu wypalenia zawodowego. Na podstawie analizy wyników badań ustalono, że zdecydowana większość badanych odczuwa występowanie stresu związanego $\mathrm{z}$ pracą $(88,6 \%)$. W oddziale chirurgii i szpitalnym oddziale ratunkowym wszyscy badani podają, że w przebiegu ich pracy występuje stres. W najmniejszym stopniu stres występuje wśród pielęgniarek w oddziale internistycznym (68,4\%). Zależności te są istotne statystycznie $(\mathrm{p}<0,004)$.

Wśród najczęściej występujących źródeł stresu badane pielęgniarki wymieniają: zbyt mała ilość personelu pielęgniarskiego $(17,4 \%)$, nadmiar dokumentacji $(16,2 \%)$, wysokie obciążenie psychiczne i duża odpowiedzialność za stan zdrowia pacjenta $(15,1 \%)$, praca $\mathrm{w}$ systemie zmianowym a głównie praca na dyżurze nocnym(10,4\%), obciążenie fizyczne $(10,0 \%)$, ryzyko zakażenia $(10 \%)$. Przedstawione źródła stresu są wymieniane jako główne w oddziale okulistycznym, chirurgicznym i w szpitalnym oddziale ratunkowym według powyższej kolejności. Natomiast w oddziale internistycznym dominującym powodem stresu jest praca zmianowa, duże obciążenie psychiczne i odpowiedzialność. Różnice jednak nie są istotne statystycznie $(\mathrm{p}<0,646)$.

W badaniach i analizie wyników uwzględniono także najczęściej występujące symptomy zespołu wypalenia zawodowego zarówno w kategorii stanów psychicznych jak i fizycznych. Wśród zdiagnozowanych występuje utrata zapału do pracy $(55,7 \%)$, gdzie najbardziej dominująca jest $w$ szpitalnym oddziale ratunkowym, a najmniej 
w oddziale okulistycznym. Stwierdzono zależność istotną statystycznie $(\mathrm{p}<0,049)$. Poczucie braku czasu występuje aż u 81,4\% badanych. Najczęściej ma ono miejsce $\mathrm{w}$ oddziale chirurgicznym a najmniej w oddziale okulistycznym. Zależności są istotne statystycznie $(\mathrm{p}<0,001)$. Badaną cechą wypalenia zawodowego było również schematyczne traktowanie pacjentów, które występuje w 31,4\%. Zachowanie to najczęściej zdarza się szpitalnym oddziale ratunkowym a najmniej w oddziale internistycznym. Różnice są istotne statystycznie $(\mathrm{p}<0,027)$. Kolejne badane symptomy wypalenia zawodowego to brak cierpliwości, obojętność i unikanie kontaktów z pacjentami pojawiające się w 35,7\%. Stany te najczęściej stwierdzono w szpitalnym oddziale ratunkowym a najmniej w oddziale chirurgicznym. Występujące różnice są istotne statystycznie $(\mathrm{p}<0,027)$. Dalsze badane objawy wypalenia zawodowego $\mathrm{w}$ kategorii stanów psychicznych nie różnią się istotnie $\mathrm{w}$ odniesieniu do poszczególnych oddziałów. Objawami tymi były: łatwe wpadanie $\mathrm{w}$ irytację i złość na członków rodziny (74,3\%), zmienność nastroju, drażliwość, lęk, gniew (55,7\%), trudności w wyrażaniu opinii lub unikanie wyrażania własnego zdania (34,3\%), bezosobowe traktowanie pacjentów i obojętność wobec problemów pacjenta $(15,7 \%)$, utrzymująca się złość i stan urazy do przełożonych i kolegów (8,6\%), uczucie pustki i braku celów życiowych $(7,1 \%)$, obecność negatywnych postaw i myśli $(7,1 \%)$.

W dalszej kolejności badaniom poddano objawy i dolegliwości fizyczne występujące wśród pielęgniarek po przebytym dyżurze, które mogą nasilać i pogłębiać właściwe objawy zespołu wypalenia zawodowego. Poczucie zmęczenia występuje bardzo często, bo aż u 74,3\% osób badanych. Najbardziej dominuje u pielęgniarek w oddziale wewnętrznym, a najmniej w oddziale okulistycznym. Różnice są istotne statystycznie $(\mathrm{p}<0,001)$. Bóle kręgosłupa są podawane aż przez $87,1 \%$ badanych. Najczęściej wymieniają je pielęgniarki z oddziału chirurgicznego, a najmniej z oddziału okulistycznego. Badane różnice są istotne statystycznie $(\mathrm{p}<0,001)$. Spośród dolegliwości tej kategorii występuje także mrowienie i drętwienie kończyn $(47,1 \%)$. Najczęściej 
dolegliwości te są wśród pielęgniarek szpitalnego oddziału ratunkowego, a najmniej u pielęgniarek oddziału okulistycznego. Stwierdzono różnice istotne statystycznie $(\mathrm{p}<0,047)$. Zaburzenia snu występują u 42,9\% osób badanych. Najwięcej zaburzeń snu jest wśród osób ze szpitalnego oddziału ratunkowego, natomiast najmniej wśród badanych z oddziału okulistycznego. Występujące różnice są istotne statystycznie $(p<0,014)$. Zaburzenia apetytu podaje bardzo nieduża liczba badanych, co stanowi 7,1\%. Najwięcej zaburzeń tego typu jest wśród badanych z oddziału okulistycznego, a w ogóle jest ich brak wśród osób z oddziału internistycznego i szpitalnego oddziału ratunkowego. Stwierdzone różnice są istotne statystycznie $(\mathrm{p}<0,012)$. Wśród badanych dolegliwości fizycznych występuje także ból głowy stwierdzony u 38,6\% badanych. Najczęściej jest on podawany przez badanych ze szpitalnego oddziału ratunkowego, a najrzadziej przez osoby $\mathrm{z}$ oddziału okulistycznego. Różnice te nie są istotne statystycznie $(\mathrm{p}<0,283)$.

Badane pielęgniarki deklarują wysoką znajomość metod radzenia sobie ze stresem, co stanowi aż 87,1\%. Różnice opinii w poszczególnych oddziałach są istotne statystycznie $(\mathrm{p}<0,042)$. Znajomość metod radzenia sobie ze stresem jest najwyższa wśród badanych w oddziale internistycznym, a najniższa wśród badanych w oddziale chirurgicznym.

Wśród badanych pielęgniarek występuje zróżnicowana znajomość środków do walki ze stresem. Najczęściej wymienianymi są: wypoczynek $(34,8 \%)$, pozytywne myślenie $(25,8 \%)$, aktywność fizyczna $(16,7 \%)$. Najrzadziej podawane to: zażywanie leków uspokajających $(1,5 \%)$ oraz stosowanie używek i aktywne życie towarzyskie $(3,8 \%)$. Różnice dotyczące wiedzy na ten temat wśród osób z poszczególnych oddziałów nie są istotne statystycznie $(p<0,943)$.

\section{Dyskusja}

Specyfika pracy $w$ oddziałach szpitalnych powoduje, że pielęgniarka jest narażona na działanie różnych czynników stresogennych. Jednym z najgroźniejszych skutków chronicznego stresu w pracy pielęgniarki jest zespół wypalenia zawodowego. Proces wypalenia za- 
wodowego jest nieuchronną konsekwencją destrukcji, która zachodzi w psychice osób nadmiernie eksploatujących swoje siły w dawaniu siebie innym. Objawy wypalenia zawodowego pojawiają się i narastają przez długi okres czasu i przechodzą przez trzy fazy, takie jak: wyczerpanie emocjonalne, depersonalizacja, zmniejszenie poczucia własnych osiągnięć [5].

Pielęgniarki uczestniczące $\mathrm{w}$ aktualnych badaniach stwierdzają jednomyślnie, że znają określenie i problematykę zjawiska wypalenia zawodowego (100\%). Taki sam stan wiedzy występuje $\mathrm{w}$ badaniach E. Kędry i K. Sanok, które to autorki podają, że wszystkie badane pielęgniarki pracujące w podmiotach leczniczych na terenie województwa dolnośląskiego posiadają wiedzę na temat wypalenia zawodowego [6]. Podobne wyniki uzyskały także A. Lewandowska i B. Litwin, gdzie $98 \%$ badanych zna zagadnienie zespołu wypalenia zawodowego [7]. Natomiast w grupie pielęgniarek operacyjnych szpitali w Białymstoku znajomość terminu „wypalenie zawodowe” deklarowało 87\% badanych [8]. Wśród pielęgniarek oddziałów neurologicznych w Gdańsku i Elblągu stwierdzono również ogólną znajomość zjawiska wypalenia zawodowego i jego cech $(61,6 \%)$ [9].

Analiza wyników badań własnych wykazała, że zespół wypalenia zawodowego wśród pielęgniarek zatrudnionych w oddziałach szpitalnych kształtuje się na poziomie średnim. Niski poziom wypalenia zawodowego dominował w grupie wiekowej 51-60 lat, a jako wysoki poziom w grupie 31-40 lat. Jednocześnie zaobserwowano, że wysoki poziom wypalenia zawodowego występuje najczęściej u osób z krótkim stażem pracy, to jest od 1 roku do 10 lat, natomiast niski poziom wypalenia posiadają najczęściej osoby ze stażem pracy od 21-30 lat. Pielęgniarki z wykształceniem wyższym magisterskim posiadają niski poziom wypalenia zawodowego, a z wykształceniem średnim zawodowym prezentują wysoki poziom wypalenia. Zdecydowana większość pielęgniarek w pracy jednozmianowej określa poziom wypalenia jako niski, a poziom wysoki występuje w pracy wielozmianowej. Jako poziom wysoki wypalenia zawodowego występuje w oddziałach 
zabiegowych, a poziom niski jest charakterystyczny dla oddziałów niezabiegowych. Wśród badanych osób, które odczuwają niską satysfakcję $\mathrm{z}$ wykonywanej pracy występuje wysoki poziom wypalenia zawodowego. Autorzy innych badań, w składzie M. Wyderka, H. Kowalska, Szeląg E. podają, że miejsce pracy pielęgniarek ma wpływ na stopień nasilenia objawów dwóch komponentów wypalenia zawodowego, to jest wyczerpania emocjonalnego i obniżonego poczucia dokonań osobistych. Natomiast w badaniach tych nie zaobserwowano wyraźnego wpływu miejsca pracy na stopień nasilenia objawów depersonalizacji. W wynikach badań powyższych autorek podano również, że jako „bardzo obciążającą” pracę pod względem fizycznym i psychicznym ocenia $100 \%$ pielęgniarek z oddziału intensywnej opieki medycznej, $90 \%$ z oddziału internistycznego i tylko $20 \%$ z oddziału pediatrycznego [10]. Z badań wykonanych przez K. Wojciechowską i D. Krzyżanowskiego wynika, że istnieje zależność między warunkami pracy a poziomem wypalenia zawodowego. Im są gorsze warunki środowiska pracy tym wyższy jest poziom wypalenia zawodowego [11].

Zjawisko stresu zawodowego jest obecne w pracy pielęgniarki i występuje na wysokim poziomie. $W$ badaniach własnych stwierdzono, że przeważająca większość osób odczuwa stres związany z pracą. W oddziale chirurgicznym i szpitalnym oddziale ratunkowym wszyscy badani podają, że w przebiegu ich pracy występuje stres. W najmniejszym stopniu stres występuje wśród pielęgniarek w oddziale internistycznym. Podobne wyniki prezentują autorzy badań przeprowadzonych w Powiatowym Szpitalu w Lipsku gdzie specyfika pracy pielęgniarki miała wpływ na odczuwanie stresu związanego z pracą zawodową. Pielęgniarki pracujące $w$ oddziałach zabiegowych odczuwały większy stres niż pielęgniarki pracujące w oddziałach zachowawczych [12].

Wśród najczęściej występujących źródeł stresu badane pielęgniarki oddziału okulistycznego, chirurgicznego i w szpitalnym oddziale ratunkowym podają zbyt małą ilość personelu pielęgniarskie- 
go, nadmiar dokumentacji, wysokie obciążenie psychiczne, dużą odpowiedzialność za stan zdrowia pacjenta, pracę w systemie zmianowym a głównie pracę na dyżurze nocnym, obciążenie fizyczne, ryzyko zakażenia. Natomiast w oddziale internistycznym dominującym powodem stresu jest praca zmianowa, duże obciążenie psychiczne i odpowiedzialność.

Zespół wypalenia zawodowego charakteryzuje się określonymi symptomami w kategorii stanów psychicznych, emocjonalnych i fizycznych, które podlegały także aktualnym badaniom. Wśród badanych pielęgniarek najczęściej występujące objawy wypalenia zawodowego to: poczucie braku czasu $(81,4 \%)$, łatwe wpadanie w irytację i złość na członków rodziny (74,3\%), zmienność nastroju, drażliwość, lęk, gniew (55,7\%), utrata zapału do pracy $(55,7 \%)$, trudności w wyrażaniu opinii lub unikanie wyrażania własnego zdania $(34,3 \%)$, schematyczne traktowanie pacjentów $(31,4 \%)$, brak cierpliwości, obojętność i unikanie kontaktów z pacjentami $(35,7 \%)$.

Ocenie podlegały także dolegliwości fizyczne, które występują wśród pielęgniarek po przebytym dyżurze i mogą przyczyniać się do pogłębienia objawów zespołu wypalenia zawodowego. Wśród najczęściej podawanych dolegliwości są: poczucie zmęczenia (74,3\%), bóle kręgosłupa, mrowienie i drętwienie kończyn $(47,1 \%)$, zaburzenia snu (42,9\%), ból głowy $(38,6 \%)$, zaburzenia apetytu $(7,1 \%)$.

Wśród badanych pielęgniarek występuje wysoka znajomość metod radzenia sobie ze stresem $(87,1 \%)$. Znajomość metod radzenia sobie ze stresem jest najwyższa wśród badanych w oddziale internistycznym, a najniższa wśród badanych w oddziale chirurgicznym. Wśród badanych pielęgniarek stwierdzono zróżnicowaną znajomość środków do walki ze stresem. Najczęściej wymienianymi są: wypoczynek $(34,8 \%)$, pozytywne myślenie $(25,8 \%)$, aktywność fizyczna $(16,7 \%)$. Najrzadziej podawane to: zażywanie leków uspokajających $(1,5 \%)$ oraz stosowanie używek i aktywne życie towarzyskie $(3,8 \%)$. Podobne wyniki uzyskały A. Lewandowska i B. Litwin, które podają, że najczęstszym sposobem radzenia sobie ze stresem jest wypoczy- 
nek bierny (27\%) i wypoczynek czynny (22\%). Ponadto pielęgniarki te poszukują wsparcia u członków rodziny, koleżanek z pracy (65\%) lub wśród przełożonych (28\%), a 7\% nie rozmawia o swoich problemach [7]. Wyniki badań J. Ogińskiej i R. Żuralskiej również potwierdzają powyższe dane. Autorki tych badań podają także, że w walce ze stresem duże znaczenie posiada uzyskanie wsparcia ze strony najbliższych i współpracowników jak również różne formy aktywnego lub biernego wypoczynku [9]. Według G. Dębskiej i G. Cepuch najistotniejszymi strategiami radzenia sobie ze stresem było poszukiwanie wsparcia oraz koncentracja na zadaniu, które ma wpływ na modyfikację działania [5]. Pozytywne sposoby radzenia sobie ze stresem występują również wśród grupy pielęgniarek pracujących w oddziałach chirurgicznych szpitali w Lublinie i w Biłgoraju. Pielęgniarki chirurgiczne wskazują na duże znaczenie wsparcia, pozytywnego myślenia i aktywności fizycznej w aspekcie obniżania poziomu stresu zawodowego [8].

\section{Wnioski}

1. Charakter pracy pielęgniarek $\mathrm{w}$ oddziałach szpitalnych różnicuje poziom zjawiska zespołu wypalenia zawodowego. Wyższy poziom wypalenia zawodowego występuje w oddziałach zabiegowych w porównaniu z oddziałami zachowawczymi.

2. Praca pielęgniarek $\mathrm{w}$ systemie wielozmianowym powoduje wystąpienie wyższego poziomu wypalenia zawodowego niż praca jednozmianowa.

3. Pielęgniarki mające niskie poczucie satysfakcji zawodowej prezentują wyższy poziom wypalenia zawodowego.

4. Pielęgniarki znają i potrafią identyfikować symptomy zjawiska wypalenia zawodowego, jak również sposoby radzenia sobie ze stresem i przeciwdziałania jego ujemnym skutkom. 


\section{Zalecenia dla praktyki pielęgniarskiej}

Dla przeciwdziałania zjawisku wypalenia zawodowego wśród pielęgniarek należy kształtować i wzmacniać pozytywne czynniki środowiska pracy jak również doskonalić relacje międzyosobowe $\mathrm{w}$ zespole terapeutycznym oraz z pacjentem i jego rodziną, a także rozwijać umiejętności asertywnego postępowania i radzenia sobie ze stresem. Zachowania te mogą znacząco redukować syndrom wypalenia zawodowego, zwiększać poczucie satysfakcji zawodowej oraz wpływać na poziom i jakość świadczonej opieki pielęgniarskiej.

\section{Bibliografia/Bibliography:}

1. Haor B., Głowacka M., Rybka M., Ślusarz R., Humańska M. Wybrane uciążliwości $\mathrm{w}$ środowisku pracy pielęgniarek opieki długoterminowej a stres i wypalenie zawodowe. W: Głowacka M. (Red.), Pielęgniarstwo a rynek pracy. Wybrane aspekty opieki pielęgniarskiej. Wydawnictwo PWSZ w Płocku, Płock 2014;45-52.

2. Dębska G., Cepuch G. Wypalenie zawodowe u pielęgniarek pracujących w zakładach podstawowej opieki zdrowotnej. Problemy pielęgniarstwa. 2008;16(3):273-275.

3. Kędra E., Sanak K. Stres i wypalenie zawodowe w pracy pielęgniarki. Pielęgniarstwo i Zdrowie Publiczne. 2013;3(2):119-132.

4. Lewandowska A., Litwin B. Wypalenie zawodowe jako zagrożenie w pracy pielęgniarki. Annales Akademiae Medicae Stetinensis. Rocznik Pomorskiej Akademii Medycznej w Szczecinie. 2009;55(3):86-89.

5. Płotka A., Mulawa J., Makara-Studzińska M., Szymona K., Karakuła H. Kowal A. Zespół wypalenia zawodowego w grupie pielęgniarek oddziałów chirurgicznych. Annaleswypalenia zawodowego Universitatis Mariae Curie-Skłodowska Lublin - Polonia. 2005;(LX)7:163169. 
6. Ogińska J., Żuralska R. Wypalenie zawodowe wśród pielęgniarek pracujących na oddziałach neurologicznych. Problemy Pielęgniarstwa. 2010;(18)4:435-442.

7. Wyderka M., Kowalska H., Szeląg E. Wypalenie zawodowe jako problem występujący wśród pielęgniarek. Pielęgniarstwo Polskie. 2009;(34)4:265-275.

8. Wojciechowska K., Krzyżanowski D. Wpływ warunków pracy na poziom wypalenia zawodowego wśród pielęgniarek operacyjnych. Pielęgniarstwo i Zdrowie Publiczne. 2011;3(1):235-244.

9. Nowak-Starz G., Kozak B., Zdziebło K. Wpływ stresu związanego z pracą zawodową na występowanie zespołu wypalenia zawodowego u pielęgniarek pracujących w oddziałach zabiegowych i zachowawczych. Studia Medyczne. 2013;29(1):15-21. 